\title{
Рецензии. Обзоры
}

\author{
УДК 94(470.51)"1918”(045)
}

\section{Е.Г. Ренёв}

\section{ИЖЕВСКО-ВОТКИНСКОЕ ВОССТАНИЕ: НОВОЕ О СТАРОМ}

В настоящей работе рассматривается тема современного состояния исследования Ижевско-Воткинского антибольшевистского восстания. Основой её стал анализ книги Е. Ф. Шумилова «О мятеже на тихом Иже» (2018), в которой была сделана заявка на новое прочтение темы, в основание чего, будто бы, были положены новые источники и не менее новые подходы к ним.

Ключевые слова: Ижевско-Воткинское восстание, историография, Народная Армия, Красная Армия, вооружённые силы.

DOI: $10.35634 / 2412-9534-2020-30-4-674-686$

Около двух лет назад в Ижевске (и не только) отмечалось 100-летие Ижевско-Воткинского антибольшевистского восстания (8 августа - 13 ноября 1918 г.) - самого мощного и упорного выступления рабочих против «диктатуры пролетариата» в российской гражданской войне. По этому поводу в городах восстания прошёл ряд мероприятий, в том числе и весьма нелепых: типа реконструкции первого дня восстания на площадке музея Ижевска. Но особенно, конечно, ожидались научные публикации, в которых давалось бы новое прочтение восстания, представлялись бы новые документы, связанные с ним и др. Одной из самых ожидаемых была и новая книга главного знатока истории Ижевска Е. Ф. Шумилова «О мятеже на тихом Иже» [31]. Анализу узловых её моментов посвящена данная статья.

Первое. Сам автор и в своей книге, и в интервью СМИ заявил о неких своих новых подходах и открытиях в истории восстания. С одной стороны, Е. Ф. Шумилов обозначил её как «документальноисторический очерк», с другой стороны, заявил, «что только в этой книге читатели впервые смогут ознакомиться с полной хронологией массового выступления ижевцев против большевиков. Она тщательно и объективно воссоздана автором на основе многочисленных документов и газетной хроники тех лет. Впервые показываются глубинные истоки и отдалённые последствия этого вооружённого конфликта» [31, с. 2].

Второе - о методологии. В другом месте своей работы Е. Ф. Шумилов заявляет: «Очевидно, что многие авторы, писавшие о восстании, нарушали принципы историзма, а они должны включать в этом конкретном случае выявление истоков восстания, определение движущих сил и организационных структур повстанцев (мятежников), установление территориальных и хронологических границ восстания (мятежа), хронологическую последовательность в изложении взаимообусловленных событий, а также хотя бы понять позицию противоборствующей стороны.

Всё это есть в моей книге. Она содержит самый полный на данный момент свод реальной, максимально объективной информации о политической, военной, производственной, культурной и повседневной жизни города-завода в дни восстания и предшествовавший ему период. Принципиальная новизна книги также в детальном обосновании причин восстания <... $>$, предпочтение по возможности отдаю не субъективным воспоминаниям, а подлинным документам или газетной хронике тех сумбурных дней» [31, с. 17-18].

При этом заявлен и сам метод: «В современной исторической науке есть статистические, чуть ли не математические, методы. Можно и так. Но я действую по старинке - через людей, их биографии и характеры, через поток взаимосвязанных событий. Это позволяет сделать сейчас вывод о сверхзадаче повстанцев» [31, с. 81-82].

При этом особо оговаривается: «Данная книга не претендует на высокий статус научной монографии, являясь лишь документально-художественным очерком <..>. Было бы бессмысленно ради никчёмной "наукообразности” загромождать текст очерка ссылками на множество порой взаимно противоречащих друг другу источников по сотням приводимых у меня исторических фактов.

Для образца в следующем приложении публикую часть важных подлинных документов <...> . 
Остальные архивные документы <..> были тщательно изучены, сопоставлены с другими документами и лишь конечная, уточнённая, сводная информация разнесена по всем главам моего повествования» [31, с. 225].

Задачи Е. Ф. Шумиловым поставлены большие, методология заявлена. Для решения этих задач автором привлекаются документы из ижевских архивов: ЦГА УР (в конце книги их перечень приводится), а также ЦДНИ УР, ФСБ по УР и др., описания которых, впрочем, нет. Вместе с ними используется информация из ижевских газет времён восстания, а также из сарапульских газет «Прикамье» и «Труженик», как утверждается в книге, за «август - сентябрь 1918 года» [31, с. 228], хотя последняя из них выходила до конца августа 1918 г., а первая - в сентябре - начале октября того же года. Хронология восстания, представляется, в основном восстановлена по этим источникам. С этой стороны она действительно достаточно полная. Но подводит почти полное отсутствие документов противоположной стороны, к примеру, боевых сводок Красной армии, сохранившихся в РГВА (копии части из них имеются в рукописном фонде УИИЯЛ Уро РАН). Более того, вне внимания автора остались документы Ижевской, Воткинской и Сарапульской Народных армий, представленные в Российском государственном военном архиве и связанные с ними документы этого архива, а также документы Восточного фронта Красной армии, собранные в нём. К последним, среди прочих, относятся оперативные сводки штаба 2-й армии Восточного фронта за сентябрь 1918 - июль 1919 г. [ф. 3; 106, оп. 3].

Не представлены в работе и документы таких архивов, как ГА РФ и др., не говоря уже о латышских архивах, местных российских архивах, архивных фондах США и др.

О понятии восстания и его причинах. Главным посылом разбираемой работы стало категорическое отрицание автором самого понятия Ижевско-Воткинское восстание как надуманного: «это застарелый штамп и симулякр». «Воткинское восстание <...> было порождено ижевскими событиями, став составной частью Ижевского восстания. Главное в том, что единый центр управления ижевцами и воткинцами действовал очень недолго и неэффективно. О совместных же боевых действиях вообще никому ничего неизвестно $<\ldots>$. Да, в умах повстанцев витали абстрактные мечтания о возможной военной взаимопомощи в критической ситуации, чего так и не случится. Сначала восставшие ижевцы заняли Воткинск, помогли подняться на борьбу коллегам-фронтовикам, вооружили их, а затем каждый город-завод будет стремиться действовать сам по себе» [31, с. 15].

Как «открытие ижевского учёного» этот вывод подхватила местная и центральная пресса. «Термин «Ижевско-Воткинское восстание» - это застарелый штамп, некий симулякр (копия, не имеющая оригинала в реальности. - Прим. ред.), миф, созданный колчаковской пропагандой и красноармейскими стратегами, представление о каком-то возможном боевом сотрудничестве ижевцев и воткинцев, которого на самом деле не было, - сказал историк» [30]. Или: «Я доказываю: не было никакого Ижевско-Воткинского восстания. Было Ижевское восстание, распространившее свою власть также на Сарапул, Елабугу, другие города. Я говорю об уникальности и самоценности Ижевского восстания. Наши братья - воткинцы пускай сами разберутся, к кому себя причислять, как называть. Нужно ли привязывать их события к нашим. Но историческая реальность, а я привык верить документам, а не умозаключениям исследователей-историков, говорит о том, что, судя по документам, никакого Ижевско-Воткинского восстания не было, - считает автор книги...

В моей книге нет никаких фантазий, всё основано на архивных документах, многие из них опубликованы тут же полностью, в приложении» [28].

Это умозаключение представляется, мягко говоря, чересчур категоричным. Ему существует и прямо противоположное мнение о том, что восстание в Прикамском районе должно называться Воткинско-Ижевским. Его высказал ныне широко известный исследователь и издатель А. В. Коробейников после того, как пару месяцев посвятил теме восстания: «Иное дело Воткинско-Ижевские повстанцы. Воткинск в этом сочетании мы ставим на первое место. Да, Ижевцы делали винтовки тысячами $<\ldots>>$ сам рабочий, который десятки лет простоял у верстака или станка, “ширкая” напильником одну и ту же деталь ружья, к переменам не восприимчив <..>. Но Воткинцы - другое дело <...>, попав в новую ситуацию после восстания 17 августа, Воткинцы буквально на следующий день $<\ldots>$ приобретают средства, которых не было у повстанцев из рабочей среды, наверное, ни до, ни после: они создают военную Галевскую флотилию $<\ldots>$ » [10, с. 93-94]. По мнению автора, именно с этой флотилией не решилась вступить в боевой контакт флотилия Ф. Раскольникова. Хотя в чём особая роль этой флотилии, слабо вооружённой и оснащённой, из текстов работ ижевского историка до сих пор остаётся непонятным. 
Другой пример последствий такого энтузиазма - сочинение воронежского историка Н. Зайца «Тупик третьего пути: очерк об Ижевско-Воткинском восстании». Автор её выступил с заявкой на истинное прочтение истории восстания, на самом деле предложив малограмотную компиляцию из ряда известных работ $[7 ; 21]$.

Как тут не вспомнить сцену из бессмертного сочинения Фонвизина из жизни семейства Простаковых:

«Правдин. Нельзя лучше. В грамматике он силён.

Милон. Я думаю, не меньше и в истории.

Г-жа Простакова. То, мой батюшка, он ещё сызмала к историям охотник...

Г-жа Простакова. <..> Мне поверь, батюшка, что, конечно, то вздор, чего не знает Митрофанушка.

Стародум. О, конечно, сударыня. В человеческом невежестве весьма утешительно считать всё то за вздор, чего не знаешь» [27].

Первое в связи с этим: в документах Красной армии от самого начала до его конца это событие обычно обозначается как «мятеж в Ижевско-Воткинском районе» [4, л. 6; 12, л. 21; 1, с. 60, 81-82]. Далее, территория восстания подчинялась общему политическому руководству - Прикомучу, во главе которого стоял воткинский кооператор, депутат Учредительного собрания Н. И. Евсеев. Через всю документацию и прессу восстания проходят постановления - от политической организации территории до экономических решений. В конце концов, именно за ним оставалось решение и важнейших военных вопросов - от объявления об объединении вооружённых сил восстания, мобилизации до смещения военного руководства. Именно по его решению был смещён с должности командующего Прикамской армии Д. И. Федичкин, на его место назначен начальник штаба Воткинской армии Юрьев, а Ижевскую армию возглавил командовавший до этого воткинцами А. Г. Журавлёв.

Наш журнал ещё в 2013 г. опубликовал материал об ижевце А. Г. Журавлёве - командире сначала Воткинской, а потом Ижевской народной армии [22, с. 179-184; 2], в котором на основе конкретных документов о совместных действиях ижевцев и воткинцев, в частности, рассказывается: «До назначения на пост командующего Ижевской Народной армией Журавлёв почти два месяца командовал Воткинской Народной армией. И руководил он её боевыми действиями достаточно удачно. Воткинская армия значительно раньше Ижевской усилиями Журавлёва и Юрьева была реорганизована из полупартизанских отрядов в регулярную двухбригадную боевую единицу, в то время как в Ижевской Народной армии этот процесс начался несколько позднее и так и не был завершён до конца восстания. В сентябре 1918 г. воткинцы вместе с ижевскими частями подошли близко к Глазову и Чепце, на северо-востоке держали фронт около Оханска, на левом берегу Камы вели бои около Осы Пермской губернии. Они же нанесли серьёзный удар по отряду Блюхера, несколько раз опрокидывали в Каму отряды Аплока, сдерживали атаки 7-го Бауского Латышского стрелкового полка, самого боеспособного полка красных на этом участке, и т. д. Обо всём этом говорит и А. Г. Ефимов, единственно забывая упомянуть, что командовал ими “бестолковый” [по определению Ефимова. - E. P.] капитан Журавлёв» [22, с. 179].

И ещё «о совместных же боевых действиях» ижевцев и воткинцев, о которых «вообще никому ничего неизвестно». На основе документооборота Красной армии, о которых Е. Ф. Шумилову «ничего неизвестно», на сегодняшний день установлено, что именно в совместной контратаке двух ижевских ударных рот и двух рот воткинцев, когда поражение восстания было уже предрешено, был разбит Ижевский Советский полк и другие силы красных, среди которых были и латышские стрелки (особенности орфографии оригинала сохранены).

\section{«ТЕЛЕГРАММА}

Штарм 2 В.[ятские] Поляны Комштаба района Вятку Оперод Аралову Наштарм 3 Пермь Аплоку Оса Лунцу Игринское Якушур Бадья Тауману Мишкино Журавлеву Гинет Чужегово [из] Дебесштаба

Дебесы, 31 октября 3 часа

оперативная и разведывательная сводка карта 10 в. в дюйме

Согласно приказу части дивизии 30 октября с утра перешли в наступление но были встречены в свою очеред пративником перешедшим в свою очеред в наступление и открывшим сильный артиллерийсуий огон по Мишкино. Гаступление пративника на Мишкино было озстановлено точка Одно- 
временно с артиллерийским обстрелом с Мишкиным пративник силой 800 человек повел назтупленье со стороны Липовка и Сред Кивары на Ильинском и Кленовка несколько атак на Кленовку было отбито но чазти Ижевскаго полка занимавшие Ильинское обратились в бегство Во время отступления командный созтав сдерживая бегущих и пытаяс возстановит положенье понес чувствительные потери. Направленый на поддержку батальон из Чужегово не смог возстановит положенье и батальон ижевцев отошли к мосту скобка на карте нет на реке Иварцы к западу от Чужегово скобка направленные на памощ батальон латышей новгородцев за наступленьем темноты не смогли возстановит паложенье Судьба батальонов ижевцев с 2 орудиями бывших в Кленовке пака не выяснена повидимаму он там держится точка Батальон володарцев в Литовени так же имел бой с пративником [результаты] коего коего еще не выяснены точка <...> По словам перебезчика сигодня на Ильинском и Кленовку наступало 4 роты общей численностью 800 чел[о]в[е]к при чем из них были 2 ударных из добровольцев Ижевскаго завода[.] Ети ижевские роты созставляют так называемый карательный отряд точка № 687. Помнаштадив Гейзлер» [23, ф. 169, оп. 1, д. 87, л. 302-302об].

О том же в Р.В.С. Второй армии днем позже:

\section{«ТЕЛЕГРАММА}

Военсовет 2 Вятския Поляны

1 Ноября Шарканы Сообщаю подробности отступления леваго фланга 30 октября от Ильинскаго двоеточие согласно приказу по дивизии Ижевский [Советский. - E. P.] полк утром 30 октября перешел наступление от Ильинскаго и Кленовки на Липовку и большую дорогу $5 /$ ю ротами имея в резерве 4 роты а всего располагая 1100 штыков 4 орудия 15 пулеметов точка Противник также наступал имея 4 роты около 800 человек при 2-х пулеметах точка во встречном бою наши роты отступили от Ильинскаго на Чужегово высланные резервы бежали бес боя несмотря на огромный перевес числа и огня с отступленьем резервнаго батальона из Чужегова оказался отрезанным с 2/мя орудиями в Кленовке точка 2 батальона Ижевскаго полка непреследуемые неприятелем бежали Малое Мосино несмотря на заградительный пулеметный огон которым их пыталис остановит взвод артиллерии бывший Чужегове удалос вывести орудия покинутыя пехотой отстреливалис до последняго снаряда $<\ldots>$ артиллерия и пулеметы растреливали густые цепи белых смыкавшиеся под огнем и продолжавшие наступат после пяти часового боя батальон отступил безпорядке<...>» [23, ф. 169, оп. 1, д. 87, л. 306-307].

В это же время воткинцы, поддерживаемые ижевцами, вели наступление на северо-востоке по обоим берегам Камы на части Аплока:

\section{«ТЕЛЕГРАММА}

Военный совет 2-й Армии <...>

1 ноября 1918 г.

Оперативная 10 час 15 мин карта 10 в. в дюйме. Противник в 6 часов перешел в наступление на наши части в районе села Частых точка По видимому противник желает прорвать наш фронт между Частыми Верхним Кокуем точка Сила противника более трех тысяч штыков точка Назтупают густыми колоннами точка наши части перешли в контрназтупление точка Аплок» [23, ф. 169, оп. 1, д. 87, л. 304].

Помимо этого, стоит отметить, что на 18 сентября уже почти три недели существовала объединённая Прикамская армия (куда вошли Ижевская, Воткинская и Сарапульская Народные армии). Воткинскую армию как её часть возглавлял ижевец штабс-капитан А. Г. Журавлёв, начальником её снабжения стал присланный из Ижевска же бывший полковник Де Ливрон [29, ф. p-548, оп. 1, д. 1, л. 9, 31] и т. д. Более того, ижевцы в Воткинской народной армии заняли не только то, что должны были занять как оружейники, а именно, возглавили команды по ремонту и сбору оружия, получили назначение «на должность Заведывающаго огнестрельными припасами артиллерийскаго отдела» и т. п. Но и занялись тем, чем, казалось бы, должны были заниматься воткинцы как производители паровозов - возглавили целый ряд важнейших железнодорожных станций. Из приказа № 14 «по Штабу народной армии города Воткинска 7 Сентября 1918 года»: «§ 3. Командированные Военным Штабом Народной Армии гор. Ижевска, оружейные техники: Ник. Лучихин и Александр Чигвинцев назначаются мною коменданта- 
ми: Первый ст. Воткинск Камско-Воткинской ж. д., а второй ст. Воткинск Московско-Казанской ж. д. $<\ldots>$ § 6. Командированные Военным Штабом Народной Армии гор. Ижевска, оружейные техники П. Я. Лужбин и А. Н. Никулин назначаются мною комендантами: Первый ст. Галево, а второй ст. Метляки Камско-Воткинской ж. д.» [23, ф. 39552, оп. 1, д. 1, л. 15-20].

Осталась отчего-то незамеченной Е. Ф. Шумиловым и опубликованная в газете «Ижевский защитник» оперативная сводка «От Штаба Воткинской армии» за 11 сентября, в которой сообщалось: «Сайгатский участок: Наши части с боем заняли село Фоки, Богородское и продвинулись на линию с левой стороны до село Дубровского и с правой стороны - до Михайловского завода войдя в связь с Ижевскими войсками» [9].

После этого воткинские части появляются на Агрызском фронте, который держат вместе с ижевцами, причём неудачно. За бездарную потерю Сарапула и Агрыза 4 и 5 октября 1918 г., случившуюся по вине высшего военного командования, под суд «за побег с Агрызскаго» фронта были отданы воткинцы - «13 солдат 4 и 5 маршевых рот» [23, ф. 39552, оп. 1, д. 1, л. 44-45; 17, с. 55-56].

В целом, стоит отметить, что документов о текущей боевой деятельности - телефонограмм, телеграмм, записей «переговоров по прямым проводам» между ижевцами и воткинцами сохранилось мало. Но то немногое, что дошло до нас, ставит под сомнение заявление Е. Ф. Шумилова, что действовали они раздельно. Так, сразу после победы восстания в Воткинске 17 августа возникает плотная переписка между ижевцами и воткинцами по поводу решения различных артиллерийских вопросов. Уже 23 августа инспектор артиллерии Ижевска предписывает командиру артиллерийского парка (служебная телеграмма № 166): «В виду отправления 1-й легкой батареи на Воткинское направление прошу содержать на Казанском вокзале готовый парк в двойном количестве, имея в виду, что 1-й батарее неразорвавшиеся снаряды (нашего снаряжения) будут более полезны, чем для 2-й бат., стоящей на Агрызском направлении» [29, оп. 1, д. 1, л. 9].

Ровно через неделю в Воткинск из Ижевска были посланы работники для решения проблемы, возникшей после работы ижевской батареи: «В артиллерийский парк 1918 г. 30 дня Августа месяца 3 час. 45 мин. Дня для $2<\ldots>$. Высылаю двух рабочих, предложенных отделом снабжения Н.[ародной] Ар.[мии] <...> в Воткинский завод для поднятия орудия, затонувшего в Каме. Вместе с названными рабочими необходимо послать на Воткинское направление наблюдателя взвода Кузнецова, который видел, как от выстрела нашей батареи перевернулась шаланда и упало орудие с нее $<\ldots>$ выполнить спешно <...>» [29, оп. 1, д. 1, л. 17].

Почти сразу же начинается поиск совместного решения таких проблем, как изготовление замков к захваченным орудиям, обмена оснасткой для снарядов, панорамами и угломерами для артиллерийских орудий и др. После того, как ижевцы отбили наступление на город частей АнтоноваОвсеенко и захватили трехдюймовое орудие [17, с. 10-12], они решают проблему с замком к нему и поначалу пытаются изготовить его сами: «Инспектор артиллерии обороны гор. Ижевска 20 августа 1918 г. № 143. Помощнику Директора Оружейного завода. Спешно закажите мастерской замок полевому 3-х дюймового орудий образца 1902 года с запасными частями. За инспектора артиллерии Бабушикин» [29, ф. р-460, оп. 1, д. 1, л. 7].

Похоже, что у ижевцев это не получилось и чертежи отправили в Воткинск, что следует из телеграммы оттуда в Ижевск: «<...> Инспектору артиллерии из Воткинского штаба № 9. 31 августа Воткинск. Ленточного пороху, капсюлей для гильз нет. Спешно высылайте Воткинск, отдел технического снабжения чертежи замков (для) пушек. Инженер Калачев» [29, ф. p-460, оп. 1, д. 1, л. 20].

Что и было исполнено: «Отдел Технического снабжения Народной армии 1 сентября 1918 г. г. Воткинск. Инспектору артиллерии г. Ижевска. Чертежи орудийных замков в количестве 6 листов получены; и пущены в работу пока 5 замков, через неделю будут готовы и пересланы в Ижевск <...>» [29, ф. p-460, оп. 1, д. 1, л. 23]. Замки, судя по всему, были изготовлены.

Переписка шла и по поводу, казалось бы, совсем малосущественных вещей: «Телеграмма № 111. Из Воткинска в Ижевс. Штаб. Наштаб. Прошу возвратить 2 полевых телефона и катушку кабеля, взятые в Воткинске командиром батареи Кузнецовым. Крайне необходимо. За Наштаб. Шадрин» [29, ф. Р-460, оп. 1, д. 1, л. 26].

Шёл обмен и личным составом: «1918 г. 4 дня сентября месяца 23 час. № $5<$...>. Согласно распоряжениям из Штаба армии пароход сейчас выходит, для встречи около Сайгатки с пароходом, идущим из Воткинска. Из Сарапула на пароход прибыли 51 офицер для усиления Ижевской армии» [29, ф. p-460, оп. 1, д. 1, л. 29]. 
Об интенсивности отношений между обеими армиями, думается, свидетельствует и то, что на 21 сентября «Отношение Воткинской Народной армии» в Ижевск имеет № 859: «§ 3. Прибывшего из Штаба Воткинской Народной армии гражданина И. А. КУРГАНОВА зачислить в списки лиц, состоящих в резерве при штабе формирования. Справка: Отношение Воткинской Народной армии за № 859» [29, ф. р-460, оп. 1, д. 1, л. 81].

Далее, в конце октября начинается объединение различных частей ижевцев и воткинцев под руководством Юрьева и Журавлёва. Начался этот процесс, видимо, с приказа главнокомандующего за № 13 от 31 октября (1918 г., Воткинск), отдельным параграфом которого предписывалось объединение средств связи: «§ 3. Признавая необходимым упорядочить дело телеграфной и телефонной связи боевых участков Ижевской и Воткинской армий, назначаю общим руководителем службы связи обеих армий начальника Штаба Воткинской армии Штабс-капитана Шадрина с подчинением ему всех должностных лиц этой категории и с оставлением его в занимаемой должности <...» $[23$, ф. 39562, оп. 1, д. 2, л. 51об].

Вслед за этим были продолжены мероприятия по «объединению действий и задач артиллерии» обеих армий, начатые ещё при создании Воткинской Народной армии, артиллерию которой создавали ижевцы: «Приказ по Ижевской Народной Армии № 78. 5-го ноября 1918 г., гор. Ижевск <...>. $\S 4$. Инспектора артиллерии Ижевской Народной армии штабс-капитана Волкова назначаю Инспектором артиллерии армий Прикамскаго края. Приказываю штабс-капитану Волкову отправиться в гор. Воткинск для ознакомления с условиями боевой работы Воткинской артиллерии и для проведения мероприятий по объединению действий и задач артиллерии Прикамскаго края <...>» [23, ф. 39562, оп. 1, д. 2, л. 59-60об].

Этим же приказом (§ 2) под эгидой ижевской «Инженерной части» создавалась общее инженерно-сапёрное подразделение для обеих армий: «<..> Воткинский Сапёрный батальон войдёт тогда в подчинение Ижевскому начальнику инженеров, который будет тогда непосредственно подчинён Главкокамску» [23, ф. 39562, оп. 1, д. 2, л. 59].

При этом, по документам видно, что «Инженерная часть» создавалась как разноплановое и достаточно крепкое подразделение, что и способствовало успешной переправе через Каму после поражения восстания [17, с. 103-106].

Примечательно то, что западная историография с самого начала своего развития рассматривала повстанцев Ижевска и Воткинска как сопряжённое явление. Радола Гайда, под командование которого в конце 1918 г. перешли воткинцы, уже в первом издании своих воспоминаний 1921 г. писал: «Но рабочие [Ижевска и Воткинска. - E. P.], подготовившие к сопротивлению около 10000 штыков, отбивали атаки большевистских войск <...> (“Ale dělnictvo, připravené k odporu v počtuasi 10000 bodáků, odolávaloк útokům bolševických vojsk<...”") [32, s. 184]. Также он утверждал, что ижевцы и воткинцы во время восстания «при подходе чехословацких войск из Закамья совместно с русским отрядом генерала Люпова воевали на нашем фланге» [3, с. 90]. Как именно Ижевско-Воткинское восстание рассматривается во всей западной историографии (хотя она нам, конечно, не указ) до сегодняшнего дня не анализировалось [34].

Ну и крайнее, но не последнее: документы разведки Красной армии и после поражения восстания свидетельствуют о совместных действиях ижевцев и воткинцев: «Телеграмма. В. Поляны Командарм 2 Шорину. 21.111918 г. 21.50. Доношу разведкой пешей и конной четвертого полка удалось выяснить следующее противник занимает деревни Верхний и Нижний Армязь силы белых в дер. 500 человек пехоты воткинцев и второй Ижевский эскадрон <... >. Азин» $[23$, ф. 169, оп. 1, д. 256, л. $15-$ 17]; «Телеграмма Вятск. Поляны Штаб 2 арм. <...> Разведывательная сводка к 9 часам 19 декабря карта 10 верст <..> из допросов перебезчиков выяснено что против участка дивизии действовали полки белых двоеточие 17 Стерлитомакский, 16 Бирский он же Мусульманский, 4 имени Союзных держав полк, 2 Ижевский и 1 Михайловский точка <...>» [23, ф. 169, оп. 1, д. 256, л. 25-26].

Д. И. Федичкин и его воспоминания. Что касается мемуаров как источника, то Е. Ф. Шумилов обозначает воспоминания Д. И. Федичкина, опубликованные в сборнике «Ижевско-Воткинское восстание. 1918 г.» (издательство «Посев») [26, с. 64-77], как «наиболее ценные для нас воспоминания $<\ldots>>$ » [31, с. 257] и приводит данные из них как достоверные. В то время как ещё более 10 лет назад на страницах нашего журнала было доказано, что публикация «Посева» и других последующих изданий суть существенное искажение основного содержания подлинника мемуаров бывшего командующего сначала Ижевской, а потом и Прикамской Народной армии [18, с. 158-161]. 
Вместе с указанной статьёй в «Вестнике Удмуртского университета» была опубликована и подлинная рукопись воспоминаний бывшего командира Прикамской (до начала сентября 1918 г. — Ижевской) Народной армии. После чего она ещё несколько раз воспроизводилась [25].

О самом бывшем командире Ижевской армии Е. Ф. Шумилов пишет: «Из всех оставшихся в наличии строевых офицеров по принципу старшинства пришлось тогда принять одному боевому капитану. Это тамбовский унтер-офицер Дмитрий Федичкин». И далее: «Ижевские повстанцы сразу произведут Федичкина в чин полковника» [31, с. 80-81].

После этого книжку эту можно бы и отложить. Но, как учит нас «Бусидо»: 武士道的精 神, 就是死 (《Путь самурая - это смерть»); в нашем случае: 历史学家道的精神, 就是死 («Путь историка - это смерть»). Унтер-офицер - это младший командир, ещё «не до офицер», что следует, собственно, из самого немецкого названия этого чина, соответствует сержанту или младшему сержанту Советской армии - третье и четвёртое звание снизу в воинской иерархии Русской императорской армии [24]. Федичкину на момент восстания 33 года, а он — в звании чеховского унтера Пришибеева?

Звание капитана относится к старшим (обер-)офицерским чинам. Федичкин, согласно не раз опубликованным документам, произведён в штабс-капитаны 27 января 1916 г., в капитаны «за боевые отличия» - 19 июля того же года, «представлен к производству в полковники со старшинством 23 августа 1917 г.» [6, с. 439; 11, 62-63].

Полковником Федичкин прибывает в Ижевск из Казани в начале августа 1918 г., согласно сохранившемуся в его личном фонде удостоверению, в котором среди прочего говорится: «Предъявитель сего бывшего 13-го Туркестанского полка, Полковник Федичкин Дмитрий Иванович, убежавший от советской власти из города Казани 1-го августа 1918 года в Ижевский завод <..>> [33]. Да и в самом варианте «Первопоходника» воспоминаний Федичина, который для Е. Ф. Шумилова «наиболее ценен», написано: «<...> Прикамский комитет членов Всероссийского Учредительного Собрания назначил старшего из строевых офицеров <..> полковника Д. Федичкина, Главнокомандующим Прикамской Народной армией» [26, с. 67].

Почти так же этот момент описан в подлиннике воспоминаний [25, с. 5], как и следующий, в котором рассказывается «как на другой день после восстания» Федичкин именно в звании полковника сформировал отряд против первой попытки реванша большевиков со стороны Казани [26, с. 68; 25, с. 7].

Ещё один момент в связи с этим: на каком основании «Ижевские повстанцы сразу произведут Федичкина в чин полковника» (сам Е. Ф. Шумилов никаких ссылок в подтверждение своего утверждения не даёт)? В Народных армиях Комуча воинские звания, «как солдатские, так и офицерские», были восстановлены лишь в сентябре 1918 г. После этого вслед за самарцами Прикамская армия возвращает прежние воинские звания. По Ижевской Народной армии таких приказов найти пока не удалось (они отражают этот процесс, в частности, появлением указания офицерских званий в приказах со второй половины сентября 1918 г.), но в документах Сарапульской армии он существует: «Приказ № $29<\ldots>$. § 4. Сарапульская Народная Армия должна быть сформирована на началах Общегосударственных, в ней должны быть незамедлительно проведены общепринятые принципы организации. Поэтому <..> приказываю: возстановить звания и чины, как солдатские, так и офицерские; при обращении называть «гражданин-капитан», «гр. поручик», «гр. солдат», «гр. унтер-офицер» и т. д. <..>. Приказ этот принять к немедленному и неуклонному исполнению. Справка: Доклад Уполномоченнаго Всероссийскаго Учредительнаго Собрания <... $>$. Постановление Военной Комиссии Совета при Временном Комитете Членов Учредительнаго Собрания от 28 сентября с/г <...> [23, ф. 4008 , оп. 1 , д. 2 , л. $34 ; 17$, с. 51-54].

Именно вариант «Посева» использован нашим автором в его «художественно-документальном очерке». При этом нужно отметить, что крайностей этого источника Е. Ф. Шумилов избегает, это касается, в первую очередь, гипертрофированных оценок вооружённых сил восстания. Однако ряд эпизодов, которые вошли в хронику Е. Ф. Шумилова, вызывают, по меньшей мере, сомнения. Это касается, к примеру, описания первых боёв восстания, контрнаступления на Агрыз и положения перед поражением.

Ижевский историк так, по Федичкину, представляет развязку боя с частями Антонова под Ижевском 18 августа 1918 г.: «В ответ по заводскому гудку были собраны все ижевские патриоты. Дмитрий Федичкин лично повёл их в атаку» [31, с. 103]. Подобное описание боя присутствует только в обоих вариантах воспоминаний бывшего командира Прикамской армии (с огромной разницей в оценке сил противника). В них Дмитрий Иванович как-то забывает о других героях первых серьёзных 
боёв за Ижевск, упомянув только себя, своего адъютанта Попкова и друга Якова Зебзиева (коренного ижевца, сына «кафтанщика», ставшего при нём начальником штаба). По его тексту в эти дни он бился с красными отрядами по всем направлениям вокруг Ижевска: «На другой день после возстания фронтовикам $<\ldots>$ была прочитана $<\ldots>$ о движении по линии этой железной дороги отряда Красной Армии на Ижевск. По прочтении этой телеграммы Полковник Федичкин быстро сформировал из 300 , собравшихся здесь фронтовиков, отряд и тотчас же выступил с ним против наступающего противника... 14 августа отряд Красной армии, силою в 2000 человек пехоты без пушек и пулеметов [речь идет об отряде Александра Чеверева, который действовал со стороны Агрыза. $-E$. P.] наступал со стороны Казани по линии железной дороги на Ижевск. Полковник Федичкин... против наступающего отряда пошел опять с теми же 300-ми фронтовиков... 18 августа в 2 часа дня противник приблизился на 6 верст к Ижевску... Противник стал громить из леса город пушками [это был отряд АнтоноваОвсеенко, наступавший от Гольян и Сарапула. - E. P.]. Снаряды летели в город и разрывались на улицах... Главнокомандующий со своим личным адъютантом Поручиком Попковым, собрав на улицах города первых попавшихся им на глаза, вооруженных $<\ldots>$ пошли навстречу противнику в лес, где задерживали его в течении часа одним лишь ружейным огнем» [25, с. 14-15].

Однако ни в документах восстания за те дни, ни в прессе восстания имён Федичкина и тех, кого он назвал, не упоминается вовсе. Героем тех событий показывается бывший жандармский полковник А. Власов, коренной ижевец: «18-го августа вечером /отряд/ под командованием начальника Штаба Власова взял с бою с. Завьялово. Когда неприятель был почти на окраинах города и в бой были введены почти все резервы, под стройные звуки оркестра, игравшего Марсельезу, выступил отряд начальника Штаба Власова» [8].

В конце восстания произошла другая тёмная история, которую Е. Ф. Шумилов в своей хронике трактует в ключе «Посева». 15 октября Федичкин уходит с поста командующего Прикамской Народной армии (до этого исчез его начальник штаба Я. Зебзиев, командующий артиллерий Трегубов и другие начальники). Сам Федичкин в подлиннике своих воспоминаний ничего о причине отъезда не говорит, их издатели и наш автор утверждают, что он покинул Ижевск из-за разногласий с политическим руководителем восстания Н. И. Евсеевым. Последний же в показаниях чекистам в 1923 г. утверждал, что снял Федичкина с поста по причине неспособности того продолжать командование [17, c. 88-89]. Видимо, в вину ему была поставлена сдача почти без боя Агрыза и Сарапула. Агрыз, ключевую железнодорожную станцию Ижевско-Воткинского района, к примеру, отряд Чеверева удерживал против ижевцев до 20-х чисел сентября. Красные же отбили её у повстанцев с налёта, и все усилия последних вернуть её закончились неудачей, причём с большими потерями.

Сам Федичкин, по его воспоминаниям и хронике Е. Ф. Шумилова, лично участвовал в попытках контрнаступления: «6-го Октября по приказанию Главнокомандующаго части Ижевской Народной Армии в количестве 1.200 человек под командою Капитана Нилова в присутствии Главнокомандующаго полковника Федичкина с чинами полевой ставки - повели наступление на Юски в 15 -ти верстах от г. Ижевска и на голову разбили неприятеля. Уничтожили совершенно 1-й Полтавский полк Красной армии и 2 эскадрона кавалерии, захватили канцелярию полка, одно трехдюймовое полевое орудие, 700 артиллерийских снарядов, 50.000 ружейных патронов, 12 пулеметов, три походных кухни, бронированный стальной поезд и массу других трофеев: дамское приданное, сласти, игрушки... и продвинулись на 37 верст вперед от Ижевска. Только наступившая ночь да чрезвычайная утомленность людей помешали занятию узловой железнодорожной станции Агрыз» [25, с. 20-21].

Подобного описания этого эпизода в других источниках (даже работах главного историка восстания Авенира Ефимова) нет, хотя контратака ижевцев на Юски и Агрыз действительно была и последний, судя по содержанию переговоров «по прямым проводам» Азина и обмену телеграммами красного командования, действительно 6-7 октября находился под угрозой, и некоторые части Красной армии под Юсками дрогнули.

Документы Красной армии, непосредственно зафиксировавшие эти события, дают существенно иную картину. О «разгроме» Полтавского полка:

«Штаб дивизии. 7/Х. Разговор тов. Азина с Командарм. 2. <..>

Команд. $2:<\ldots>$ имеется батальон Полтавскаго полка и скажите цел он и его орудие или он разбит вдребезги, как передавал тов. Чевырев.

тов. Азин: дер. Юкос [на самом деле - Юски. $-E$. P.] занята противником, батальон разбит орудие одно 3 -х дюймовое оставлено без замка $<\ldots>$. Наличные силы $[$ красных. $-E$. $P$.] $<\ldots>$ слишком жидки <...>. 
Шорин: <..> Орудия испорченные шлите сюда. Вам пошлю на замену их новыя, а теперь скажите, что же хоть сколько нибудь от батальона бывшаго у Юски осталось что нибудь и собирают ли снова в одно целое и где?

Азин: <..> они собираются [разгромленные полтавцы. - E. P.], человек сто уже собраны. Как только соберутся больше, я дам им задачу как ротной единице, но это займет время не раньше вечера.

Шорин: очень жаль, что батальон этот дрогнул <..>. Твёрдо уверен, что вы с задачей у Агрыза и Сарапула поправитесь» [23, ф. 1328, оп. 1, д. 621, л. 6-7, 10об].

Как видим, ижевцами разгромлен только один батальон полтавцев. Скоро он будет восстановлен и примет участие в дальнейших боях.

О ситуации под Агрызом:

«Штаб дивизии. 8/X-18. Разговор т. Азина с Командармом 2 Шориным <... .

Азин: докладываю с 11 часов утра белые силою тысячи три пошли колоннами в наступление на Агрыз. Деревня Пурга переходила из рук в руки <...>. Только что закончился бой с большими потерями для белых. Артиллерия разгромила их больше тысячи, а остальные разбежались <...>. Противник на всем участке давит, поставил задачу во что бы то ни стало нас где нибудь сшибить. Но мы надеемся и оправдываем безпощадно отбиваем их. Но теперь мы жидки <... .

Командарм 2: <..> Послал телеграмму третьяго дня Троцкому, написал все подробно и прошу два полка с артиллерией выслать спешным порядком. Принимал ли участие Московский полк в бою и что сформировали из остатков Полтавского полка. Бегуны появляются и здесь [то есть в Вятских Полянах, где находится Шорин. - E. P.] <..>» [23, ф. 1328, оп. 1, д. 621, л. 12об-16].

О том же Азин сообщает начальнику штаба дивизии Пашковскому, но численность побитых им ижевцев уже в два раза меньше, чем для командарма: «8 Окт. Т е л е г р а м м а. Сарапул. <..> у нас был сегодня горячий бой за Агрыз белые чуть не завладели Агрызом но мы как развернулись так от них лишь лапти полетели убитых у них около 500 человек» [23, ф. 1328, оп. 1, д. 83, л. 116].

О последнем член РВС 2-й армии С. И. Гусев сообщал Троцкому: «<..> за все бои был единственный случай беспорядочного отступления у Юсек, севернее Агрыза» [23, ф. 1, оп. 2, д. 80, л. 283285]. Но контратака эта азинцами была ликвидирована с большими потерями для ижевцев. Из оперативной сводки от 7 октября 1918 г., 22.00:

«<..> Ижевское направление. Противник пытается прорваться к Агрызу с линии Юськи, Ст. Постол, Большая Норья, но отбивается нашими энергичными контратаками» [23, ф. 6, оп. 4, д. 945, л. 65.].

Кроме того, А. Нилов не мог в эти дни командовать наступлением ижевцев, так как оставил пост командующего Агрызским фронтом ещё 20 сентября (приказ № 19 по Сарапульской Народной армии [23, ф. 4008, оп. 1, д. 2, л. 24]), и имя его в последующем документообороте отсутствует.

Артиллерия повстанцев неожиданно (после того, как было уже давно доказано совершенно обратное [13; 14]), предстает у Е. Ф. Шумилова грозной силой: «Наша артиллерия быстро станет самой грозной силой у повстанцев <...>» [31, с. 107].

«Середина сентября. Артиллерийский дивизион Ижевской Народной армии состоит уже из трёх легких батарей, горной (№ 4) и тяжёлой (№ 5). Командный состав - 13 человек.

$<\ldots>20$ сентября. $<\ldots>$ У повстанцев уже набралось 16 орудий и 50 пулемётов. Командует артиллерийским дивизионом Кузнецов. Он всего лишь прапорщик, но командиром у него [так кто кому командир? - E. P.] служит штабс-капитан Яковлев <...> [31, с. 107].

Откуда почерпнуты эти сведения - неизвестно, ссылок никаких нет. Как и то, куда из этих 16 орудий накануне последних боёв делось 5, в документах Красной армии нет ни одного сообщения о захвате к тому времени у ижевцев хотя бы одной пушки.

Далее автор пишет: «На 1 ноября ижевцы будут располагать тремя трёхдюймовыми и пятью шестидюймовыми полевыми орудиями, двумя трёхдюймовыми и одной полуторадюймовой горными пушками. Всё это в полной боевой готовности. Для одной трёхдюймовки, захваченной в бою 6 октября, ижевцы смогли изготовить новый замок.

Ко всему этому арсеналу имеется 3500 разнокалиберных гранат, шрапнелей и бомб, а для связи 12 телефонных аппаратов и 18 верст кабеля» [31, с. 137, 139].

В последнем автор повторяет умозаключение своих извечных оппонентов П. Н. Дмитриева и К. И. Куликова, утверждавших, что «<..> за короткий срок, то есть за 25 дней, удалось создать полнокровный артдивизион. <..> Дивизион состоял из 5 рот [на самом деле батарей, как это и указано в 
документах. - E. P.], в каждой из которых было по 3 взвода. Три роты были вооружены лёгкими орудиями, одна - горными и одна - тяжёлыми 6-дюймовыми орудиями. $<\ldots>$ офицеров и солдат было всего 320 человек» [5, с. 103-104].

Но обратим внимание на сам документ, на основании которого Е. Ф. Шумилов делает вывод (конечно без ссылок) о некоей силе артиллерии восставших:

«Сведение о количестве артиллерийского имущества, состоящего в Артиллерийском дивизионе Ижевской Народной армии на 1 ноября 1918 г.» [29, ф. p-460, оп. 1, д. 2, л. 151-151об]

\begin{tabular}{|l|l|}
\hline Наименование имущества & Количество \\
\hline Орудий & \\
\hline $3 "$ полевых & 3 \\
6" & 5 \\
3" горных & 2 \\
1 1²" & 1 \\
\hline 3арядных ящиков & 5 \\
\hline Орудийных патронов & \\
\hline Гранат 3" полевых & 1484 \\
Шрапнелей 3" & 1414 \\
\hline Гранат 3" полев. Ижевских & 280 \\
Шрапнелей 3" & 55 \\
\hline Бомб 48 линейных & 57 \\
\hline Телефонное имущество & 57 \\
\hline Аппаратов & \\
\hline Кабеля & 12 \\
\hline
\end{tabular}

Он, действительно, свидетельствует о наличии у ижевцев 11 орудий: 5 легких, одном - полуторадюймовом и 5 тяжёлых. Вот только снаряды есть лишь к первым 5 трёхдюймовым орудиям!

У противника к тому времени только у наступавших на Ижевск с юга и юго-востока полевых частей их было не менее чем в 10 раз больше! Их совокупный залп мог смести любое сопротивление (и это, не считая артиллерии Особой Вятской дивизии, наступавшей с севера, и артиллерии флотилии Раскольникова). Более того, эти 5 лёгких орудий должны были действовать по всему периметру обороны Ижевска, и потому на линии главного удара Красной армии с юга от Завьялова до Веньи документами последних боёв Восстания фиксируется действие только трех из них [19, с. 144-147].

Почти 10 лет назад автор этих строк уже доказал в своих расчётах, что «грозная» артиллерия ижевцев, а тем более - воткинцев, суть не что иное, как, по выражению Е. Ф. Шумилова, «симулякр», придуманный советскими историками при участии некоторых эмигрантских авторов [15; 16] ещё в начале 20 -х гг. прошлого столетия [13; 14]. И никто до сих пор даже запятую из этих выводов под сомнение не поставил.

Заключение. «Художественно-документальный очерк» Е. Ф. Шумилова «О мятеже на тихом Иже» в своей художественной ипостаси имеет безусловное значение в описании событий Ижевского восстания через установление хронологии, наполнение её определёнными событиями и людьми с их судьбами. Но документальная часть и концепция восстания вызывают определённые сомнения как по общим выводам и отдельным вопросам, так и по работе с документами в целом. Последние не только никак не атрибутируются, но и зачастую берутся весьма некритически. Отсюда - это книга, хотя и занимательна, но во многом, увы, далека от науки. Тем не менее, хочется надеяться, что проблемы, поднятые в ней, будут разрабатываться дальше.

\section{СПИСОК ИСТОЧНИКОВ И ЛИТЕРАТУРЫ}

1. 2 Армия в боях за освобождение Прикамья и Приуралья: 1918-1919: документы. Устинов: Удмуртия, 1987. $316 \mathrm{c}$.

2. Биография гражданина Журавлёва Александра Георгиевича, бывшего штабс-капитана империалистической войны и участника Ижевского восстания в 1918 году / публ. Е. Г. Ренёва // Ренёв Е. Г. Вооружённые силы Ижевского восстания: этапы и особенности формирования. Ижевск: ИжГТУ, 2016. С. 224-231. 
3. Гайда Р. Вступление в Русскую армию // Мои воспоминания (пер. М. Ситникова) // Иднакар. 2014. № 1 (18) C. 82-93.

4. Директива Главного командования Реввоенсовету 2 армии о возложении на него командования объединенными силами по подавлению Ижевско-Воткинского мятежа от 14 сентября 1918 г. // Российский государственный военный архив (РГВА).

5. Дмитриев П. Н., Куликов К. И. Мятеж в Ижевско-Воткинском районе. Ижевск: Удмуртия, 1992. 338 с.

6. Ефимов А. Г. С ижевцами и воткинцами против большевиков на восточном фронте. Статьи, письма, документы / сост. Л. Ю. Тремсина; коммент. С. В. Волкова. М.: Айрис-пресс, 2013. 560 с.

7. Заяи Н. Тупик третьего пути: очерк об Ижевско-Воткинском восстании // Научно-просветительский журнал «Скепсис». 2012. Декабрь. URL: http://scepsis.net/library/id_3351.html

8. Ижевский Защитник. 1918. 23 авг. № 1.

9. Ижевский защитник. 1918. 13 сент. № 9.

10. Коробейников A. В. Волжская флотилия против Народной армии. Ижевск: Иднакар, 2012.98 с.

11. Первопоходник. 1974. № 17.

12. Приказ войскам армии о ликвидации Ижевско-Воткинской группировки противника от 16 октября 1918 г. // Российский государственный военный архив (РГВА).

13. Ренёв E. Г. Артиллерийское вооружение и боеприпасы Ижевской Народной армии накануне решающих сражений // Иднакар. 2012. № 1 (14). С. 81-110.

14. Ренёв E. Г. Артиллерия Ижевской Народной армии накануне решающих сражений // Исторические, философские, политические и юридические науки, культурология и искусствоведение. Вопросы теории и практики. 2011. № 7 (13). Ч. 3. С. 169-172.

15. Ренёв Е. Г. Вооружённые силы Ижевского восстания в ранней советской историографии // Вестн. МГОУ (Электронный журнал). 2014. № 1. С. 10.

16. Ренёв Е. Г. Вооружённые силы Ижевского восстания в поздней советской историографии // Вестн. МГОУ История и политические науки. 2014. № 2. С. 21-30.

17. Ренёв Е. Г. Вооружённые силы Ижевского восстания: этапы и особенности формирования. Ижевск: Изд-во ИжГТУ, 2016. 239 с.

18. Ренёв Е. Г. Воспоминания Д. И. Федичкина как источник по изучению Ижевского анти-большевистского восстания // Вестн. Удм. ун-та. Вып. 3. Сер. История и филология. 2011. С. 158-161.

19. Ренёв Е. Г. Заводы в огне. Ижевские заводы и вооружение Ижевской народной армии во время антибольшевистского восстания. Ижевск: Изд-во ИжГТУ, 2014. 184 с.

20. Ренёв Е. Г. Красная армия против Ижевского восстания. Осень 1918 года. Ижевск: Изд-во ИжГТУ, 2013.282 с.

21. Ренёв Е. Г. Новые «открытия» в историографии Ижевско-Воткинского восстания // Иднакар. 2013. № 1 (16). C. $117-145$.

22. Ренёв Е. Г. Последний командир Ижевской Народной армии (из архивных фондов Управления ФСБ по Удмуртской республике) // Вестн. Удм. ун-та. Сер.: История и филология. 2013. Вып. 3. С. 179-184.

23. Российский государственный военный архив (РГВА).

24. Система воинских званий в Российской Императорской Армии. URL: https:/www.rusempire.ru/arkhivstatej/1881-sistema-voinskikh-zvanij-v-rossijskoj-imperatorskoj-armii.html

25. Федичкин Д. И. Ижевское возстание в период с 8 августа по 15 октября 1918 года. Написано для Hoover War Library Stanford University California командовавшим Ижевским восстанием Д. Федичкиным, бывшим полковником 13-го Туркестанского Стрелкового полка Российской Армии. 5 October 1931. San Francisco, California // Hoover institution archives. Box № 1, folder ID: XX37-8.31 / публ. Е.Г. Ренева // Ренёв Е.Г. Красная армия против Ижевского восстания. Осень 1918 года. С. 194-223.

26. Федичкин Д. И. Ижевское восстание в период с 8-го августа по 20 октября 1918 года // Ижевско-Воткинское восстание 1918 г. / под ред. В. Ж. Цветкова. М.: Посев, 2000. С. 64-77.

27. Фонвизин Д. И. Недоросль // Собр.соч.: в 2 т. М.; Л.: ГИХЛ, 1959. Т. 1. С. 105-177.

28. Цветухина М. Ижевско-Воткинское восстание: хроника без фантазий // Известия Удмуртской Республики. 2018. 15 нояб. С. 30

29. Центральный государственный архив Удмуртской Республики (ЦГА УР).

30. Шамаева Я. Мятеж на Иже. В столице Удмуртии отметили 100-летие Ижевско-Воткинского восстания // Российская газета. Неделя - Приволжье. 2018. 16 авг.URL: https://rg.ru/2018/08/16/reg-pfo/uchenyj-razveialmify-ob-izhevsko-votkinskom-vosstanii-1918-goda.html

31. Шумилов Е. Ф. О мятеже на тихом Иже. Год 1918-й. Ижевск: Удмуртия, 2018. 272 с.

32. Gajda R. Moje paměti: Generál ruských legií R. Gajda. Československá anabase zpět na Urál proti bolševikům Admirál Kolčak. 4. vydání. Brno: Jota, 1996. 352 s.

33. Hoover institution archives. Box № 1, folder ID: XX37-8.31.

34. Retish A.B. Russia's Peasants in Revolution and Civil War: Citizenship, Identity, and the Creation of the Soviet State (1914-1922). N. Y.: Cambridge University Press, 2008. 294 p. Pp. 179-188. 
Ренёв Евгений Геннадьевич, кандидат исторических наук, доцент кафедры «Философия и социология» ФГБОУ ВО «Ижевский государственный технический университет имени М. Т. Калашникова» 426069, Россия, г. Ижевск, ул. Студенческая, 7

E-mail: egr@idz.ru

\section{E.G. Renev \\ THE IZHEVSK-VOTKINSK REVOLT: THE NEW ABOUT THE OLD}

DOI: $10.35634 / 2412-9534-2020-30-4-674-686$

The article is devoted to the Izhevsk-Votkinsk workers' revolt, which was the most powerful unrest against the Bolsheviks in 1918. The author analyzes the work of E.F. Shumilov "About Riot in the Quiet Izh River's Area". Shumilov's book made a request for a new reading of the topic, in the basis of which, allegedly, there were new sources and new approaches to them. The author of the article argues that the new ideas of that book are not new in reality. The most among them have not solid foundation.

Keywords: Izhevsk-Votkinsk workers' revolt, historiography, the People army, the Red Army, armed forces.

\section{REFERENCES}

1. 2 Armiya v boyah za osvobozhdenie Prikam'ya i Priural'ya: 1918-1919: dokumenty [The 2nd Army in the battles for the liberation of Prikamye and Ural: 1918-1919: documents]. Ustinov, "Udmurtiya" Publ., 1987. 316 s.

2. Biografiya grazhdanina Zhuravleva Aleksandra Georgievicha, byvshego shtabs-kapitana imperialisticheskoj vojny i uchastnika Izhevskogo vosstaniya v 1918 godu [The Biography of citizen Zhuravlev Alexander Georgievich, former headquarters captain of the imperialist war and participant in the Izhevsk uprising in 1918]. Renev E. G. Vooruzhennye sily Izhevskogo vosstaniya: etapy i osobennosti formirovaniya [Armed forces of the Izhevsk uprising: stages and features of formation]. Izhevsk, ISTU Press, pp. 224-231.

3. Gajda R. Vstuplenie v Russkuyu armiyu [The Joining the Russian Army]. Moi vospominaniya [My Memoirs]. Idnakar, 2014, no. 1 (18), pp. 82-93.

4. Direktiva Glavnogo komandovaniya Revvoensovetu 2 armii o vozlozhenii na nego komandovaniya ob'edinennymi silami po podavleniyu Izhevsko-Votkinskogo myatezha ot 14 sentyabrya $1918 \mathrm{~g}$. [The Directive of the High Command to the Revolutionary Military Council of the 2nd Army on assigning command of the combined forces to suppress the Izhevsk-Votkinsk rebellion of September 14, 1918]. Rossiyskiy gosudarstvennyy voyennyy arkhiv (RGVA) [Russian State Military Archive].

5. Dmitriev P. N., Kulikov K. I. Myatezh v Izhevsko-Votkinskom rajone [The Rebellion in the Izhevsk-Votkinsk district]. Izhevsk, "Udmurtiya" Publ., 1992, 338 p.

6. Efimov A. G. S izhevcami i votkincami protiv bol'shevikov na vostochnom fronte. Stat'i, pis'ma, dokumenty [With Izhevsk and Votkintsy against the Bolsheviks on the eastern front. Articles, letters, documents]. Moscow, "Ajrispress" Publ., 2013, 560 p.

7. Zayac N. Tupik tret'ego puti: ocherk ob Izhevsko- Votkinskom vosstanii [The Dead End of the Third Way: Essay on the Izhevsk-Votkinsk Uprising]. Skepsis, 2012, Dec. URL: http://scepsis.net/library/id_3351.html

8. Izhevskij zashchitnik [The Izhevsk Defender]. 1918, Aug., 23, no. 1.

9. Izhevskij Zashchitnik [The Izhevsk Defender]. 1918, Sept., 13, no. 9.

10. Korobejnikov A. V. Volzhskaya flotiliya protiv Narodnoj armii [The Volga flotilla against the People's Army]. Izhevsk, "Idnakar" Publ., 2012, 98 p.

11. Pervopohodnik [The Pioneer], 1974, no. 17.

12. Prikaz vojskam armii o likvidacii Izhevsko-Votkinskoj gruppirovki protivnika ot 16 oktyabrya 1918 g. [The Order to the army forces on the liquidation of the Izhevsk-Votkinsk enemy grouping of October 16, 1918]. Rossiyskiy gosudarstvennyy voyennyy arkhiv (RGVA) [Russian State Military Archive].

13. Renev E. G. Artillerijskoe vooruzhenie i boepripasy Izhevskoj Narodnoj armii nakanune reshayushchih srazhenij [The Artillery weapons and ammunition of the Izhevsk People's Army on the eve of decisive battles]. Idnakar, 2012, no. 1 (14), pp. 81-110.

14. Renev E. G. Artilleriya Izhevskoj Narodnoj armii nakanune reshayushchih srazhenij [The Artillery of the Izhevsk People's Army on the eve of decisive battles]. Istoricheskie, filosofskie, politicheskie i yuridicheskie nauki, kul'turologiya i iskusstvovedenie. Voprosy teorii i praktiki [Historical, philosophical, political and legal sciences, cultural studies and art history. Questions of theory and practice], 2011, no. 7 (13), part 3, pp. 169-172.

15. Renev E. G. Vooruzhennye sily Izhevskogo vosstaniya v rannej sovetskoj istoriografii [The Armed Forces of Izhevsk Uprising in Early Soviet Historiography]. Vestnik MGOU (Elektronnyj zhurnal) [MGOU Bulletin (Electronic journal)], 2014, no. 1, p. 10. 
16. Renev E. G. Vooruzhennye sily Izhevskogo vosstaniya v pozdnej sovetskoj istoriografii [The Armed forces of Izhevsk rebellion in late Soviet historiography]. Vestnik MGOU. Istoriya i politicheskie nauki [MGOU Bulletin. History and Political Science], 2014, no. 2, pp. 21-30.

17. Renev E. G. Vooruzhennye sily Izhevskogo vosstaniya: etapy i osobennosti formirovaniya [The Armed forces of Izhevsk rebellion: stages and features of formation]. Izhevsk, ISTU Press, 2016, $239 \mathrm{p}$.

18. Renev E. G. Vospominaniya D. I. Fedichkina kak istochnik po izucheniyu Izhevskogo anti-bol'shevistskogo vosstaniya [The Memoirs of D. I. Fedichkin as a Source for the Study of the Izhevsk Anti-Bolshevik Uprising]. Vestnik Udmurtskogo universiteta. Seriya Istoriya i filologiya [Bulletin of the Udmurt University. Series History and Philology], 2011, issue 3, pp. 158-161.

19. Renev E. G. Zavody v ogne. Izhevskie zavody i vooruzhenie Izhevskoj narodnoj armii vo vremya antibol'shevistskogo vosstaniya [The plants are on fire. Izhevsk factories and weapons of the Izhevsk People's Army during the anti-Bolshevik uprising]. Izhevsk, ISTU Press, 2014, 184 p.

20. Renev E. G. Krasnaya armiya protiv Izhevskogo vosstaniya. Osen’ 1918 goda [Red Army against the Izhevsk uprising. Autumn 1918]. Izhevsk, ISTU Press, 2013, 282 p.

21. Renev E.G. Novye "otkrytiya" v istoriografii Izhevsko-Votkinskogo vosstaniya [The New "discoveries" in the historiography of the Izhevsk-Votkinsk uprising]. Idnakar, 2013, no. 1 (16), pp. 117-145.

22. Renev E. G. Poslednij komandir Izhevskoj Narodnoj armii (iz arhivnyh fondov Upravleniya FSB po Udmurtskoj respublike) [The last commander of the Izhevsk People's Army (from the archival funds of the Office of the FSB in the Udmurt Republic)]. Vestnik Udmurtskogo universiteta. Seriya Istoriya i filologiya [Bulletin of the Udmurt University. Series History and Philology], 2013, issue 3, pp. 179-184.

23. Rossijskij gosudarstvennyj voennyj arhiv (RGVA) [The Russian State Military Archive].

24. Sistema voinskih zvanij v Rossijskoj Imperatorskoj Armii [The system of military ranks in the Russian Imperial Army]. URL: https://www.rusempire.ru/arkhiv-statej/1881-sistema-voinskikh-zvanij-v-rossijskoj-imperatorskojarmii.html

25. Fedichkin D. I. Izhevskoe vozstanie v period s 8 avgusta po 15 oktyabrya 1918 goda [The Izhevsk rebellion from August 8 to October 15, 1918]. Napisano dlya Hoover War Library Stanford University California komandovavshim Izhevskim vosstaniem D. Fedichkinym, byvshim polkovnikom 13-go Turkestanskogo Strelkovogo polka Rossijskoj Armii 5 Octyabrya 1931 g. San Francisco, California [Written for the Hoover War Library Stanford University California by the commander of the Izhevsk uprising D. Fedichkin, a former colonel of the 13th Turkestan Rifle Regiment of the Russian Army. 5 October 1931. San Francisco, California]. Hoover institution archives. Box no. 1, folder ID: XX37-8.31. Publ. E. G. Renev in: Renyov E. G. Red Army against the Izhevsk uprising. Autumn 1918, pp. $194-223$.

26. Fedichkin D. I. Izhevskoe vosstanie v period s 8-go avgusta po 20 oktyabrya 1918 goda [The Izhevsk uprising in the period from August 8 to October 20, 1918 ]. Izhevsko-Votkinskoe vosstanie 1918 g. [Izhevsk-Votkinsk rebellion 1918]. Moscow, "Posev" Publ., 2000, pp. 64-77.

27. Fonvizin D. I. Nedorosl' [The Young ignoramus]. Sobranie sochinenij v 2-h t [Collected works in 2 volumes]. Moscow; Leningrad, "GIHL” Publ., 1959, vol. 1, pp. 105-177.

28. Cvetuhina M. Izhevsko-Votkinskoe vosstanie: hronika bez fantazij [The Izhevsk-Votkinsk uprising: a chronicle without fantasies]. Izvestiya Udmurtskoj respubliki [News of the Udmurt Republic], 2018, no. 133 (4858), Nov., 15 , p. 30.

29. Central'nyj gosudarstvennyj arhiv Udmurtskoj Respubliki (CGA UR) [The Central State Archive of the Udmurt Republic].

30. Shamaeva Ya. Myatezh na Izhe. V stolice Udmurtii otmetili 100-letie Izhevsko-Votkinskogo vosstaniya [The Rebellion on Izh river. The capital of Udmurtia celebrated the 100th anniversary of the Izhevsk-Votkinsk uprising]. Rossijskaya gazeta. Nedelya - Privolzh'e [Russian newspaper. Week - Volga region], 2018, Aug., 16, no. 180 (7643). URL: https://rg.ru/2018/08/16/reg-pfo/uchenyj-razveial-mify-ob-izhevsko-votkinskom-vosstanii-1918-goda.html

31. Shumilov E. F. O myatezhe na tihom Izhe. God 1918-j [About the revolt in quiet Izhe. Year 1918]. Izhevsk, "Udmurtiya" Publ., 2018, 272 p.

32. Gajda R. Moje paměti: Generál ruských legií R. Gajda. Československá anabase zpět na Urál proti bolševikům Admirál Kolčak. 4. vydání. Brno: Jota, 1996. 352 s.

33. Hoover institution archives. Box № 1, folder ID: XX37-8.31.

34. Retish A. B. Russia's Peasants in Revolution and Civil War: Citizenship, Identity, and the Creation of the Soviet State (1914-1922) / A. B. Retish. New York: Cambridge University Press, 2008. 294 p. Pp. 179-188.

Received 20.01.2020

Renev E. G., Candidate of History, Associate Professor at Department "Philosophy and Sociology"

Izhevsk State Technical University named after M. T. Kalashnikov

Studencheskaya st., 7, Izhevsk, Russia, 426069

E-mail: egr@idz.ru 